\title{
Purification and Some Properties of Cyclodextrin Glycosyltransferase from a Strain of Bacillus Species
}

\author{
Sumio Kitahata, Naoto Tsuyama* and Shigetaka OKada \\ Osaka Municipal Technical Research Institute, Osaka, Japan \\ Received September 3, 1973
}

\begin{abstract}
An ultracentrifugally homogeneous preparation of the cyclodextrin glycosyltransferase was obtained from the culture broth of a strain of Bacillus species (No. 5 strain) by a purification methods including adsorption on corn starch, ammonium sulfate precipitation, chromatography on DEAE-cellulose column, and gel-filtration on Sephadex G-100. This enzyme preparation (No. 5 enzyme) was separated into two fractions in disc-electrophoresis and Ampholine-electrophoresis (Fr. 1: pI 6.07 and Fr. 2: pI 6.80) which had the ability to form cyclodextrin. These two fractions were similar to each other in the enzymic properties except the isoelectric point. These enzymes differ from the amylase from Bacillus macerans (BMA) in the enzymic properties. Furthermore, No. 5 enzymes differ from BMA in the action on starch. The authors consider that No. 5 enzymes mainly produce the cycloheptaamylose from starch and on the contrary, BMA mainly produces the cyclohexaamylose from starch.
\end{abstract}

Cyclodextrin glycosyltransferase- $(\alpha-1,4$-glucan 4-glycosyltransferase, cyclizing) is an unique enzyme which has the ability to convert starch to cyclodextrin (homogeneous cyclic molecules of six or more $\alpha$-D-glucopyranose units linked 1-4 as in amylose). This enzyme has also been reported to catalize coupling reactions whereby linear series of oligosaccharides are formed when $\alpha$-dextrin (cyclohexaamylose) and a cosubstrate such as glucose, maltose or sucrose are incubated with a crude enzyme preparation.

Since in 1939 Tilden and Hudson announced the discovery of a cell free enzyme preparation from cultures of Bacillus macerans which had the ability to form the cyclodextrin from starch, this enzyme (BMA) has been investigated in detail and very actively for a long time $^{1 \sim 6} \quad$ However, so far no other source, microbial or otherwise, has been found for this unique enzyme.

Recently, we have obtained direct evidence for the presence of cyclodextrin glycosyltransferases in the culture filtrates from the strains of Bacillus species different from $B$.

* Present address: Hayashibara Co., Ltd., Shimoishii, Okayama, Japan. macerans enzyme. ${ }^{7}$ The present paper contains the purification and the general properties of the cyclodextrin glycosyltransferase (No. 5 enzyme) produced by the typical strain (No. 5 strain) selected from the several strains of Bacteria isolated from soil.

\section{MATERIALS AND METHODS}

Purified Bacillus macerans amylase. Stock culture of Bacillus macerans IFO 3490 was usually cultivated in a $500 \mathrm{ml}$ of shaking flask containing $70 \mathrm{ml}$ of the medium on a reciprocal shaker at $37^{\circ} \mathrm{C}$ for $70 \mathrm{hr}$. The medium used for the production of amylase was composed of corn steep liquor $1 \%$, soluble starch $1 \%$ \% ammonium sulfate $0.5 \%$ and calcium carbonate $0.5 \%$. Solid ammonium sulfate was added to the supernatant $(2500 \mathrm{ml})$ obtained by centrifugation of the culture to $30 \%$ saturation. The mixture was cooled to $5 \% \mathrm{C}$ and then passed through a column containing a mixture of corn starch granules $(150 \mathrm{~g})$ and hyflo super-cel $(60 \mathrm{~g})$ under cooling. The adsorbed enzyme was eluted with $1200 \mathrm{ml}$ of $0.033 \mathrm{M} \mathrm{Na}_{2} \mathrm{HPO}_{4}$ and the effuent was salted out with 0.65 saturation of ammonium sulfate. The resulting precipitate was separated by filtration, dissolved in $80 \mathrm{ml}$ of the distilled water and dialyzed against the running water. The dialyzed enzyme solution $(106 \mathrm{ml})$ was applied to a DEAE-Sephadex column (19 $430 \mathrm{~mm}$ ), equilibrated with $0.01 \mathrm{M}$ tris- $\mathrm{HCl}$ buffer (pH 7.3). The column was washed with the same buffer and the enzyme was eluted with a linear gradient of sodium chloride concentration from 0 to $0.5 \mathrm{M}$ 


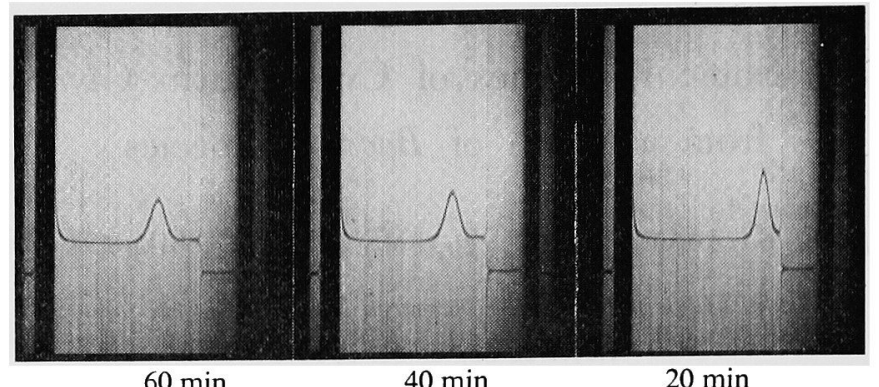

FIG. 1. Ultracentrifugal Pattern of Bacillus macerans Amylase (BMA).

Protein concentration was $9 \mathrm{mg}$ per $\mathrm{ml}^{a}{ }^{a}$ The photographs were taken at intervals as indicated after reaching $60,000 \mathrm{rpm}$. Sedimentation was carried out at $20^{\circ} \mathrm{C}$.

a) Assuming that $E_{1 \mathrm{~cm}}^{1 \%}$ at $280 \mathrm{~nm}$ was 10.0 .

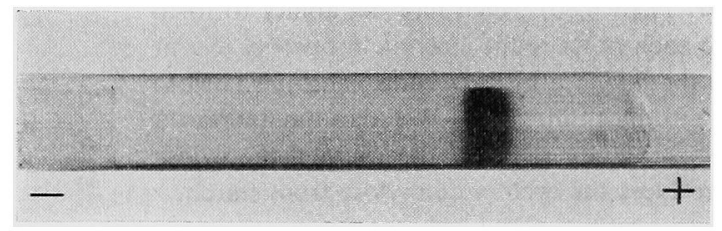

FIG. 2. Disc-electrophoresis Pattern of Purified BMA.

The purified enzyme solution, about $100 \mu$, which contained about $200 \mu \mathrm{g}$ protein, was subjected to a column of the electrophoresis at $\mathrm{pH} 9.4$ as described in the text.

in the buffer. The active fractions were combined and concentrated to $5 \mathrm{ml}$ using a collodion bag. The concentrated enzyme solution was finally purified by Sephadex G-75 gel column chromatography (17 $x$ $1400 \mathrm{~mm}$ ), equilibrated with $0.01 \mathrm{M}$ phosphate buffer (pH 7.0). The active fractions were combined and used as the purified enzyme preparation. This preparation was purified about 200 fold and the specific activity was 260 (units/O.D. at $280 \mathrm{~nm}$ ). This purified enzyme was homogeneous on the ultracentrifugation and also on the disc-electrophoresis as shown in Fig. 1 and Fig. 2.

Assay of enzyme activity. The culture liquor did not contain any significant quantity of the $\alpha$-amylse, and so the enzyme activity was measured as follows. The reaction mixture containing $0.5 \mathrm{ml}$ of enzyme solution and $4.5 \mathrm{ml}$ of $0.55 \%$ soluble starch in $0.05 \mathrm{M}$ acetate buffer $(\mathrm{pH} 5.5)$ was incubated at $40^{\circ} \mathrm{C}$ for 10 min. After that, $0.5 \mathrm{ml}$ of the reaction mixture is removed and added to $4 \mathrm{ml}$ of $0.01 \mathrm{M}$ iodine in $0.25 \mathrm{M}$ potassium iodide. This mixture was diluted to $20 \mathrm{ml}$ with the distilled water, and then the light transmission of the solution was measured at $660 \mathrm{~nm}$ in a Hitachi 181 spectrophotometer. One unit of enzyme activity was defined as the amount of enzyme which gave a linear increase of $1 \%$ transmission per minute at $40^{\circ} \mathrm{C}$.
In each step of the purification, trichloroethylene test was performed in order to check the formation of cyclodextrin.7

Analytical methods. The total sugars were measured by phenol- $\mathrm{H}_{2} \mathrm{SO}_{4}$ method. ${ }^{81}$ Iodine test is followed by the method of Tilden and Hudson microscopic test. ${ }^{2}$ Protein concentration was determined spectrophotometrically by measuring the absorbance at $280 \mathrm{~nm}$ in a Hitachi 181 spectrophotometer.

Analysis of homogeneity. Disc-electrophoresis of the enzyme preparation was carried out by the method of Davis and Nagai ${ }^{9,10)}$ at $\mathrm{pH} 9.4$ with an apparatus of M. S. Instruments Co. For the determination of the isoelectric point, isoelectric focusing was performed by the method of Matsuo ${ }^{11}$ in a $110 \mathrm{ml}$ column using carrier Ampholites ( $\mathrm{pH} 3 \sim 10$, LKB-Producter $\mathrm{AB}$, Sweden) for $64 \mathrm{hr}$ at 300 volt, $4^{\circ} \mathrm{C}$. Ultracentrifugation was carried out at $60,000 \mathrm{rpm}$ at $20^{\circ} \mathrm{C}$ with a Hitachi UCA 1 analytical ultracentrifuge.

\section{RESULTS}

\section{Purification of the No. 5 enzyme}

A Bacillus sp., strain No. 5, isolated from soil was used throughout this investigation. A variety of media was tested for the production of much more cyclodextrin glycosyltransferase activity. So far tested, the suitable medium was that consisted of wheat bran $1 \%$, polypepton $1 \%$, corn steep liquor $1 \%$, soluble starch $4 \%$ and dry yeast $0.5 \%$. The strain No. 5 was cultivated in $500 \mathrm{ml}$ of shaking flask containing $60 \mathrm{ml}$ of medium on a reciprocal shaker at $37^{\circ} \mathrm{C}$ for $70 \mathrm{hr}$. The organisms were removed from the culture liquor by centrifugation. 
The supernatant was used as the crude enzyme solution. Solid ammonium sulfate was added to the crude enzyme solution $(2000 \mathrm{ml})$ to $25 \%$ saturation, and then the precipitate was removed by filtration with Celite. The resulting clear solution was cooled to $5^{\circ} \mathrm{C}$, and charged on corn starch layer (corn starch $150 \mathrm{~g}$ and Hyflo Super-Cel $60 \mathrm{~g}$ ). The adsorbed enzyme was eluted with $960 \mathrm{ml}$ of $0.033 \mathrm{M} \mathrm{Na}_{2} \mathrm{HPO}_{4}$ and the effluent was salted out with 0.65 saturation of ammonium sulfate. After standing overnight, the precipitate was collected by filtration and dissolved in distilled water. This enzyme solution was dialyzed overnight against the running water, and the insoluble material formed was removed by centrifugation. The dialyzed enzyme solution $(180 \mathrm{ml})$ was placed on the DEAE-cellulose column $(20 \times 414 \mathrm{~mm})$, previously equilibrated with $0.01 \mathrm{M}$ Tris- $\mathrm{HCl}$ buffer $(\mathrm{pH} \mathrm{8.0)}$. Active fractions which passed through the column, were combined $(300 \mathrm{ml})$ and concentrated to $10 \mathrm{ml}$ by using a collodion bag. The concentrated enzyme solution was applied to gelfiltration with Sephadex G-75 column ( $28 \times$ $1300 \mathrm{~mm}$ ), equilibrated with $0.01 \mathrm{M}$ phosphate buffer ( $\mathrm{pH}$ 7.0). Filtration was performed with the same buffer. The elution pattern thus obtained is shown in Fig. 3. The frac-

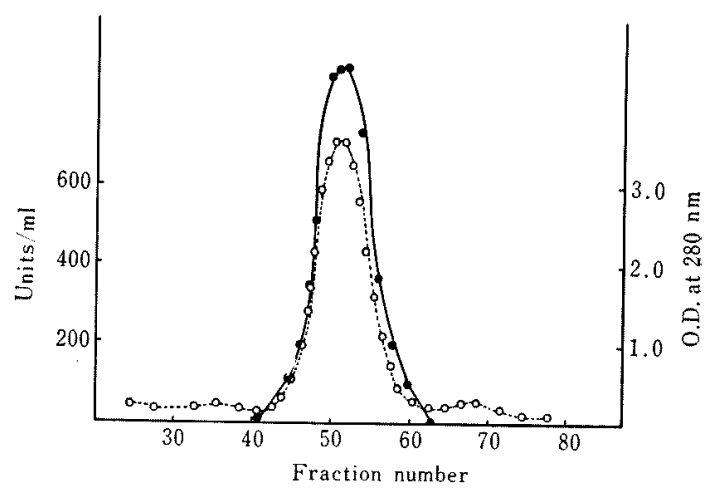

FIG. 3. Gel-Filtration of Cyclodextrin Glycosyltransferase from the Strain of No. 5 on a Sephadex G-75.

The experimental conditions are described in the text. - - activity of cyclodextrin glycosyltransferase; Om, absorbance at $280 \mathrm{~nm}$.

tions from No. 47 to No. 56 were collected and used as the enzyme preparation to examine the homogeneity. The results of the purification are summarized in Table I. The enzyme preparation of the final stage was purified about 130 -fold, and the specific activity was 258 (units/O.D. at $280 \mathrm{~nm}$ ).

\section{Homogeneity of the enzyme preparation}

In order to check the homogeneity of the enzyme preparation, ultracentrifugation, disc-

Table I. Purification Procedure of Cyclodextrin Glycosyltransferase FROM THE STRAIN OF No. 5

\begin{tabular}{|c|c|c|c|c|}
\hline & Vol. $(\mathrm{ml})$ & $\begin{array}{c}\text { Total } \\
\text { activity (units) }\end{array}$ & $\begin{array}{c}\text { Specific } \\
\text { activity } \\
\text { (units/O.D.280n })\end{array}$ & Yield $(\%)$ \\
\hline $\begin{array}{l}\text { Culture liquor } \\
\qquad \begin{array}{l}\text { Added }\left(\mathrm{NH}_{4}\right)_{2} \mathrm{SO}_{4}(0.25 \text { satn.) } \\
\text { and filtrated by celite }\end{array}\end{array}$ & 2000 & $1.34 \times 10^{5}$ & 1.91 & 100 \\
\hline $\begin{array}{l}\text { Supernatant } \\
\qquad \begin{array}{l}\text { Adsorbed on corn starch } \\
\text { and eluted by } 0.033 \mathrm{M} \mathrm{Na}_{2} \mathrm{HPO}_{4}\end{array}\end{array}$ & 2400 & $1.51 \times 10^{5}$ & 2.00 & 113 \\
\hline $\begin{array}{l}\text { Effluent } \\
\qquad \begin{array}{l}\text { Salted out with }\left(\mathrm{NH}_{4}\right)_{2} \mathrm{SO}_{4} \\
(0 \sim 0.6 \text { satn. }) \text { and dialyzed }\end{array}\end{array}$ & 960 & $1.00 \times 10^{5}$ & 14.0 & 75 \\
\hline $\begin{array}{l}\text { Dialyzed soln. } \\
\qquad \begin{array}{l}\text { Charged on DEAE-cellulose } \\
\text { and washed }\end{array}\end{array}$ & 180 & $1.06 \times 10^{5}$ & 128 & 79 \\
\hline $\begin{array}{l}\text { Effluent } \\
\qquad \begin{array}{l}\text { Concentrated and gel-filtrated } \\
\text { by Sephadex } \mathrm{G}-75\end{array}\end{array}$ & 300 & $8.05 \times 10^{4}$ & 200 & 60 \\
\hline Purified enzyme & 105 & $6.75 \times 10^{4}$ & 258 & 50 \\
\hline
\end{tabular}




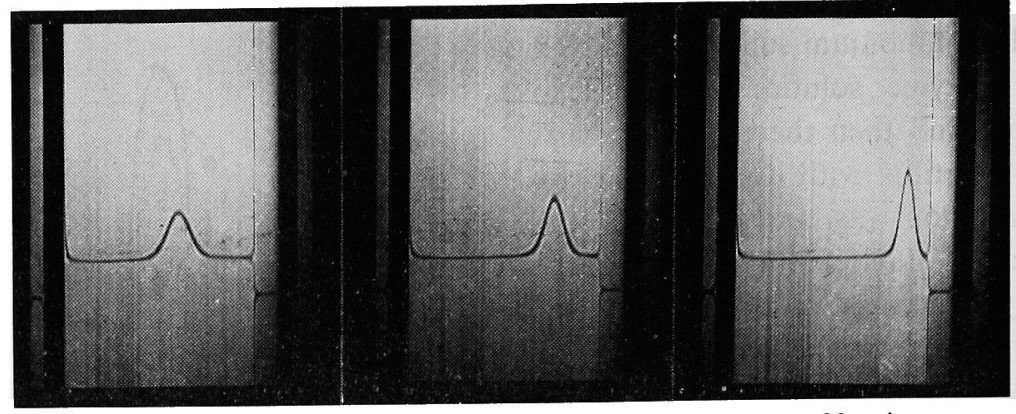

$60 \min$

$40 \mathrm{~min}$

$20 \mathrm{~min}$

FIg. 4. Ultracentrifugal Pattern of No. 5 Enzyme. The conditions were same as described in Fig. 1.

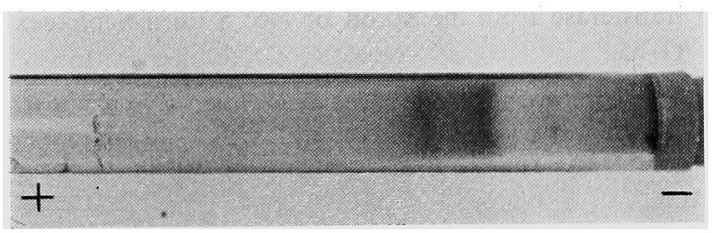

Fig. 5. Disc-electrophoretic Pattern of No. 5 Enzyme.

The conditions were same as described in Fig. 2.

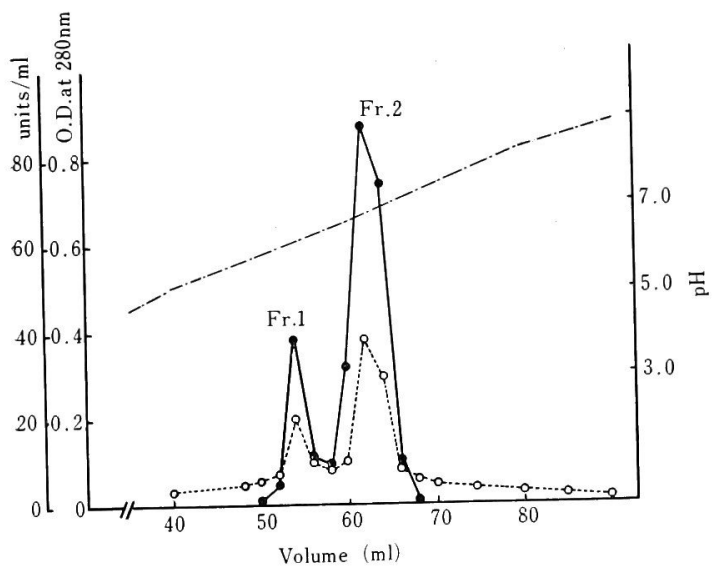

Fig. 6. Isoelectric Focusing of No. 5 Enzyme. The experiment was performed in a $110 \mathrm{ml}$ column containing carrier ampholites $\mathrm{pH} 3 \sim 10(1 \%, \mathrm{v} / \mathrm{v})$ for $64 \mathrm{hr}$ at 300 volt, $4^{\circ} \mathrm{C}$.

- - activity of cyclodextrin glycosyltransferase; ○---, absorbancy at $280 \mathrm{~nm}$; ----, pH.

electrophoresis with polyacrylamide gel and isoelectric focusing were performed. The enzyme preparation showed a single symmetrical peak in the ultracentrifuge analysis as shown in Fig. 4. However, by the discelectrophoresis at $\mathrm{pH}$ 9.4, this enzyme pre- paration gave two bands as shown in Fig. 5 . Also in the isoelectric focusing, the preparation was separated into two fractions, Fr. 1 (pI: 6.07) and Fr. 2 (pI: 6.80), both of which had the cyclodextrin glycosyltransferase activity. An electrophoretic profile is shown in Fig. 6. Therefore, in the following experiments, each fraction (Fr. 1, Fr. 2) was used as the purified enzyme preparation.

\section{$\overline{E n z y m a t i c ~ p r o p e r t i e s ~}$}

1) Effect of $\mathrm{pH}$ on activities and stabilities of three enzymes. The pH-activity curves of three purified enzymes, Fr. 1, Fr. 2 and BMA are presented in Fig. 7. These three enzymes were similarly most active in the $\mathrm{pH}$

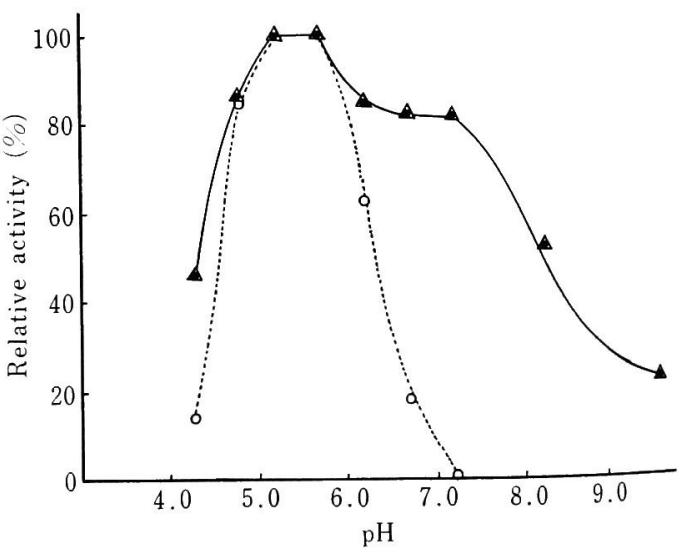

FIG. 7. pH-Activity Curves of Three Purified Enzymes of Fr. 1, Fr. 2 and BMA.

The reaction mixtures consisted of $0.5 \mathrm{ml}$ of the enzyme solution, $2.5 \mathrm{ml}$ of $1 \%$ soluble starch and $2 \mathrm{ml}$ of $0.1 \mathrm{M}$ Mcllvaine buffer, were incubated at $40^{\circ} \mathrm{C}$ for $10 \mathrm{~min}$. 
range from 5 to 5.7 , when checked by the standard assay method. However, in alkaline side the pH-activity curves of Fr. 1 and Fr. 2 were much broader than that of BMA.

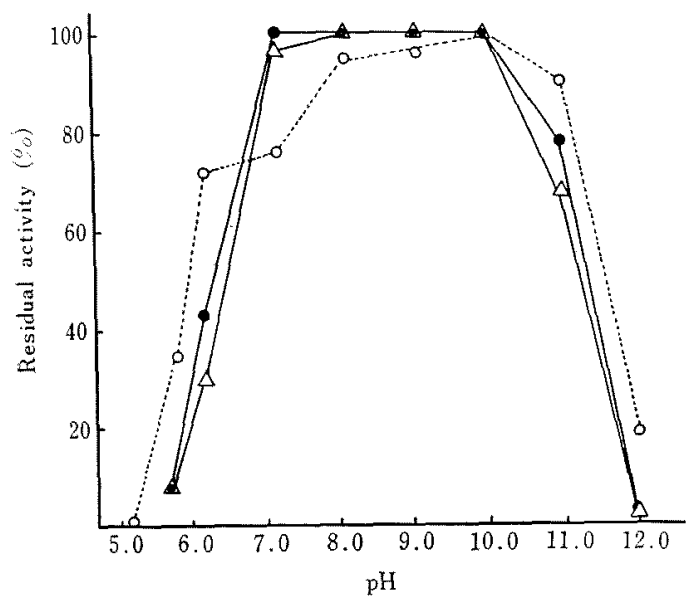

Fig. 8. pH-Stability Profiles of Three Enzymes of Fr. 1, Fr. 2 and BMA.

Aliquots of the enzyme solution $(1 \mathrm{ml})$ were incubated in $0.05 \mathrm{M}$ Mcllvaine buffer $(\mathrm{pH} 5.0 \sim 10.0)$, NaCl$\mathrm{NaOH}$-glycine buffer (pH $10.0 \sim 12.0$ ) at $40^{\circ} \mathrm{C}$ for $2 \mathrm{hr}$. After that this solution were diluted with $0.1 \mathrm{M}$ acetate buffer ( $\mathrm{pH} 5.5$ ) $4 \mathrm{ml}$ and assayed for remaining activity.

$\bullet$ Fr. $1 ; \Delta-\triangle$, Fr. 2; $-\cdots$, BMA.

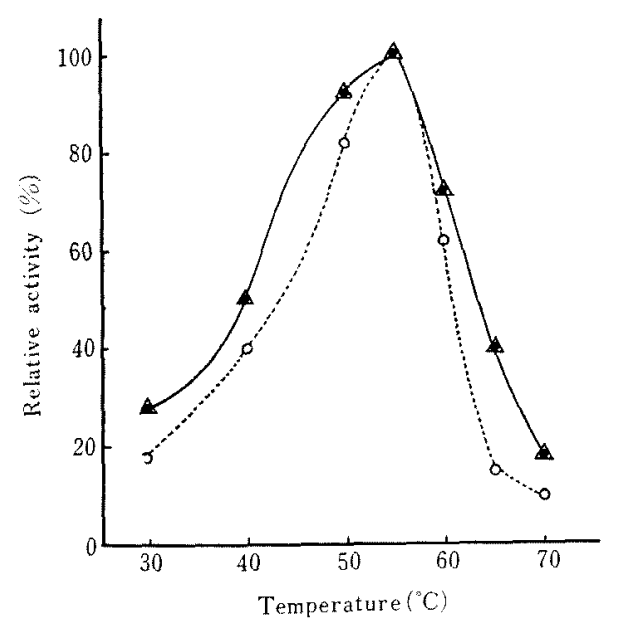

Frg. 9. Temperature-activity Relationships of Three Enzymes of Fr. 1, Fr. 2 and BMA.

The reaction mixtures consisted of $0.5 \mathrm{ml}$ of the enzyme solution, $2.5 \mathrm{ml}$ of $1 \%$ soluble starch and $2 \mathrm{ml}$ of $0.1 \mathrm{M}$ acetate buffer ( $\mathrm{pH} 5.5$ ) were incubated at the indicated temperature for $10 \mathrm{~min}$.

$\bullet$ Fr. $1 ; \triangle-\triangle$, Fr. 2; $\bigcirc-\cdots$, BMA.
To examine the $\mathrm{pH}$-stability relationships of three purified enzymes, the enzymes were incubated for $2 \mathrm{hr}$ at $30^{\circ} \mathrm{C}$ in buffer solution of various $\mathrm{pH}$ values, and the residual activities were determined at $\mathrm{pH}$ 5.5. As shown in Fig. 8, two enzymes (Fr. 1 and Fr. 2) were stable over the range of $\mathrm{pH} 7.0$ to 10.0 , and BMA was stable over the range of $\mathrm{pH} 8.0$ to 10.0.

2) Effect of temperature on activities and stabilities of three enzymes. The enzyme reaction was carried out at $\mathrm{pH} 5.5$ for $10 \mathrm{~min}$ at various temperatures. The temperature optimums for the enzyme reaction of three enzymes (Fr. 1, Fr. 2 and BMA) were about $55^{\circ} \mathrm{C}$ as shown in Fig. 9.

To check the thermal stability, these enzymes were incubated at $\mathrm{pH} 7.0$ and various temperatures, and after $10 \mathrm{~min}$, the remaining activities were assayed by the standard method. The result is shown in Fig. 10. Two enzymes of No. 5 were stable at temperatures below $55^{\circ} \mathrm{C}$, and BMA was stable at temperatures below $60^{\circ} \mathrm{C}$.

Comparison of the cyclodextrins formed by the

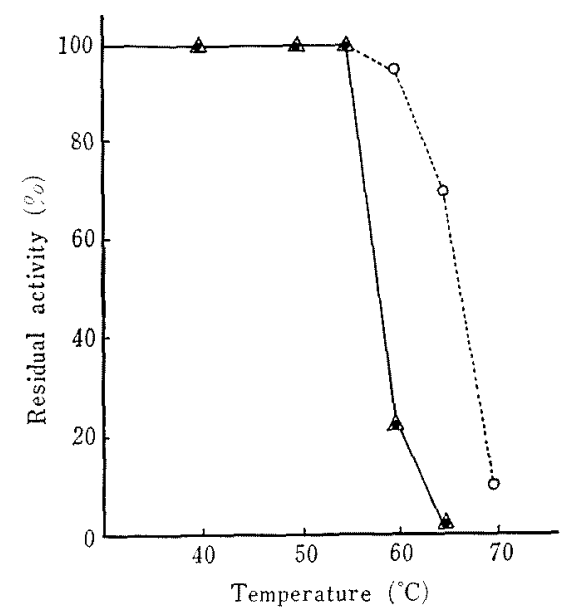

FIG. 10. Thermal Stabilities of Three Enzymes of Fr. 1, Fr. 2 and BMA.

Aliquots of the enzyme solution in $0.05 \mathrm{M}$ phosphate buffer ( $\mathrm{pH} 7.0$ ) were incubated at the indicated tamperature for $10 \mathrm{~min}$, cooled immediately at $0^{\circ} \mathrm{C}$ for $30 \mathrm{~min}$ and assayed for the remaining activities. 

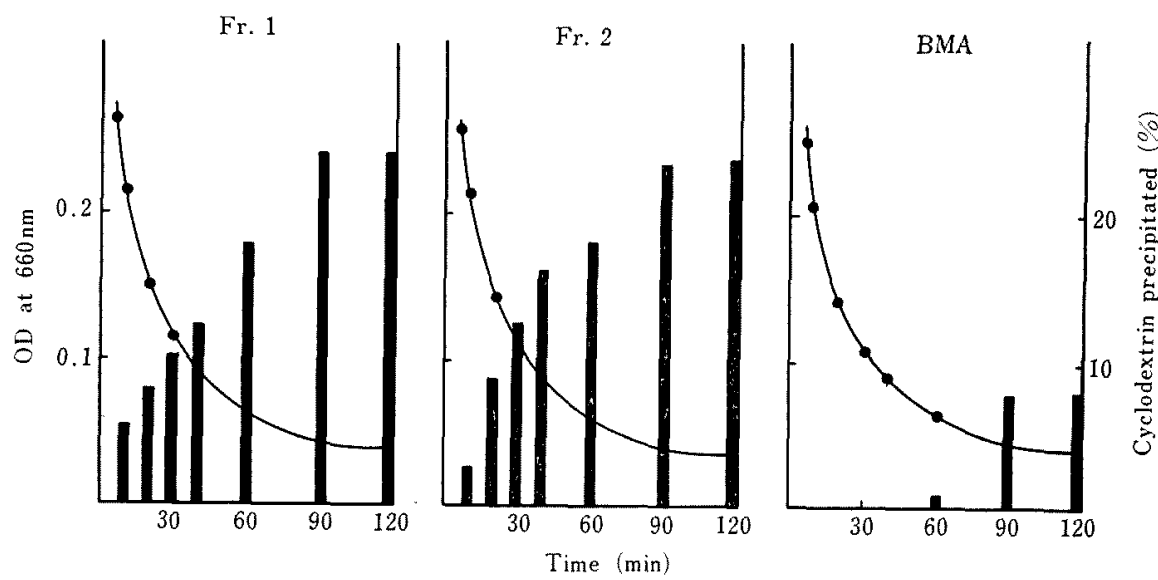

Fig. 11. Comparison of the Cyclodextrins Formed by the Action of Three Enzymes of Fr. 1, Fr. 2 and BMA on Soluble Starch.

The reaction mixtures of $3 \%$ soluble starch $(12 \mathrm{ml}$ ) and each of three enzymes ( 3 unit per $\mathrm{ml}$, $6 \mathrm{ml}$ ) were incubated at $40^{\circ} \mathrm{C}$.

- - decrease in iodine colour (blue value); chloroethylene.

action of three enzymes (Fr. 1, Fr. 2 and $B M A$ ) from starch

Each of three enzymes ( 3 units $/ \mathrm{ml}, 6 \mathrm{ml}$ ) was reacted with $3 \%$ soluble starch $(12 \mathrm{ml})$ at $40^{\circ} \mathrm{C}$. At certain intervals, $2 \mathrm{ml}$ aliquots of the reaction mixture were removed to examine the decrease in iodine color (blue value), the amounts of cyclodextrin precipitated with trichloroethylene (TCE) and its iodine test. The results are shown in Fig. 11. The decrease in iodine color of three enzymes were similar to each other. Namely, three enzymes decompose the soluble starch in the same rate. Two of No. 5 (Fr. 1 and Fr. 2) among three enzymes produced the same amounts of cyclodextrin precipitated with TCE. However, in the case of BMA the amounts of cyclodextrin precipitated with TCE were much less than that of No. 5 enzymes. In the iodine test, the cyclodextrin formed by the action of BMA formed blue hexagonal plate prisms with $\mathrm{I}_{2}-\mathrm{KI}$ and that of two enzymes of No. 5 formed yellow-brown monoclinic prisms.

\section{DISCUSSION}

The cyclodextrin glycosyltransferase produced by No. 5 strain of Bacillus spieces was purified by the following procedures: adsorption on corn starch, ammonium sulfate precipitation, chromatography on DEAE-cellulose column and gel-filtration on Sephadex G-100. The enzyme obtained was homogeneous in ultracentrifugation, but separated into two fractions in disc-electrophoresis, and ampholine electrophoresis (Fr. 1: pI 6.07, Fr. 2: pI 6.80), which had the ability to form cyclodextrin.

Two fractions of No. 5 enzymes were similar to each other in general properties such as specific activity, optimum $\mathrm{pH}$ and temperature and $\mathrm{pH}$ and temperature stability except the isoelectric point. Also in the action on starch, two fractions were similar to each other. Further detailed enzymic properties and the correlation between Fr. 1 and Fr. 2 will be described in later studies.

In order to compare No. 5 enzymes with the cyclodextrin glycosyltransferase produced by Bacillus macerans IFO 3490 (Bacillus macerans amylase, BMA), BMA was purified to an electrophoretically and ultracentrifugally homogeneous state by the same method.

BMA differs from No. 5 enzymes in enzymic properties such as in isoelectric point (BMA, pI: 4.62), optimum $\mathrm{pH}$ and temperature and 
$\mathrm{pH}$ and temperature stability. Also in the action on starch, BMA is different from No. 5 enzymes.

As shown in Fig. 11, the amounts of the cyclodextrin precipitated with TCE in the reaction mixture of BMA on starch were much less than that of No. 5 enzymes. It is reported that the solubility of the cyclohexaamylose (cyclodextrin G6) in the presence of TCE is $0.24 \mathrm{~g} / 100 \mathrm{ml}$ and the cycloheptaamylose (cyclodextrin G7) is $0.03 \mathrm{~g} / 100 \mathrm{ml}$. ${ }^{\text {) }}$ Judging from these results, it is assumed that No. 5 enzymes mainly produce the cycloheptaamylose on the contrary, BMA mainly produces the cyclohexaamylose. Furthermore, the result in the iodine test supports to this assumption. Namely, the cyclodextrin formed by the action of BMA forms the complex with iodineiodide, blue hexagonal plate prisms, which are characteristic of the cyclohexamylose. On the other hand, that of No. 5 enzymes formed the complex with iodine-iodide, yellow-brown monoclinic prisms which are characteristic of the cycloheptaamylose. Further confirmation will be described in later studies.
Acknowledgement. The authors wish to express their hearty thanks to Dr. Y. Tsujisaka in our institute for valuable advice and encouragement and Dr. S. Mantani for helpful suggestions in the preparation of this manuscript.

\section{REFERENCES}

1) E. B. Tilden and C. S. Hudson, J. Amer. Chem. Soc., 63, 2900 (1939).

2) Idem, J. Bact, , 43, 527 (1942).

3) D. French, J. Pazur, M. L. Levine and E. Norberg, J. Amer. Chem. Soc., 70, 3145 (1948).

4) J. A. Depinto and L. L. Campbell, Biochemistry, 7, 114 (1968).

5) Idem, Arch. Biochem. Biophys, 125, 253 (1968).

6) D. French, M. L. Levine, J.H. Pazur and E. Norberg, J. Amer. Chem. Soc., 71, 353 (1949).

7) S. Okada, N. Tsuyama and S. Kitahata, Amylase symposium, Japan, 7, 61 (1972).

8) M. Dubois, K. A. Gilles, J. K. Hamilton, P. A. Rebers and F. Smith, Anal. Chem., 28, 350 (1956).

9) B. J. Davis, Ann. N.Y. Acad. Sci., 121, Abst. 2,404 (1964).

10) Y. Nagai, Tampakushitsu Kakusan Koso, Bessatsu, IX, 3 (1967).

11) Y. Matsuo and T. Horio, Tampakushitsu Kakusan Koso, 12, 737 (1967). 